\title{
SISTEM PENDIDIKAN KUTTAB AL JAZARY SEBAGAI REPRESENTASI PENDIDIKAN ISLAM KLASIK
}

\section{THE EDUCATION SYSTEM OF KUTTAB AL JAZARY AS REPRESENTATION OF CLASSICAL ISLAMIC EDUCATION}

\author{
Umi Muzayanah \\ Balai Penelitian dan Pengembangan Agama Semarang \\ email: umimoza78@gmail.com
}

Naskah Diterima: 25 Februari 2020; Direvisi: 25 Maret 2020; Disetujui: 22 Agustus 2020

\begin{abstract}
The existence of Kuttab in Indonesia has recently begun to grow and develop in several regions. Starting with the establishment of Kuttab Al-Fatih in Depok and then opened branches in 22 cities, other Kuttab began to appear, one of them was Kuttab Al Jazary Surakarta. This research aims to describe the education system of Kuttab Al Jazary, including curriculum and learning methods that represent Classical Islamic education. Using qualitative methodologies, this study obtained several findings. First, the education system in Kuttab Al Jazary consists of Qur'anic education, moral education, and science education. The three education systems are representations of classical Islamic education that were implemented in the Kuttab at the beginning of Islamic development. Secondly, the learning method applied is dominated by the halaqah method especially for learning the Alquran, while the classical approach is used for learning syar'i and science.
\end{abstract}

Keywords: Classic; Islamic education; Kuttab Al Jazary

\begin{abstract}
Abstrak
Keberadaan Kuttab di Indonesia akhir-akhir ini mulai tumbuh dan berkembang di beberapa wilayah. Berawal dari berdirinya Kuttab Al-Fatih di Depok yang kemudian membuka cabang di 22 kota, kuttab-kuttab lain pun mulai bermunculan, salah satunya adalah Kuttab Al Jazary di Surakarta. Penelitian ini bertujuan untuk mendeskripsikan sistem pendidikan Kuttab Al Jazary, mencakup kurikulum dan metode pembelajaran yang merepresentasikan pendidikan Islam Klasik. Dengan menggunakan metode kualitatif, penelitian ini menghasilkan beberapa temuan. Pertama, sistem pendidikan pada Kuttab Al Jazary terdiri dari pendidikan Alquran, pendidikan adab, dan pendidikan ilmu. Ketiga sistem pendidikan tersebut merupakan representasi dari pendidikan Islam klasik yang diterapkan di kuttab-kuttab pada awal perkembangan Islam. Kedua, metode pembelajaran yang diterapkan didominasi oleh metode halaqah khususnya untuk pembelajaran Alquran, sedangkan metode klasikal dilakukan untuk pembelajaran ilmu syar'i dan ilmu umum.
\end{abstract}

Kata Kunci: Klasik; Kuttab Al Jazary; Pendidikan Islam 


\section{PENDAHULUAN}

Sistem pendidikan di Indonesia tidak saja mengakomodir pendidikan agama yang diselenggarakan di sekolah dan madrasah, melainkan juga mengakomodir kebutuhan masyarakat akan pendidikan keagamaan. Merujuk pada Peraturan Pemerintah No. 55 Tahun 2007 tentang Pendidikan Agama dan Keagamaan, bahwa pendidikan keagamaan menyelenggarakan pendidikan ilmu-ilmu yang bersumber dari ajaran agama. Fungsi pendidikan keagamaan adalah mempersiapkan peserta didik menjadi anggota masyarakat yang memahami dan mengamalkan nilai-nilai ajaran agamanya dan/atau menjadi ahli ilmu agama. Secara teknis, pendidikan keagamaan dapat diselenggarakan dalam bentuk pendidikan formal, nonformal, dan informal.

Masih pada regulasi yang sama, pendidikan keagamaan Islam yang diatur berbentuk madrasah diniyah dan pesantren. Kedua bentuk pendidikan keagamaan Islam, baik pesantren maupun madrasah diniyah ini sudah tidak asing bagi masyarakat Muslim, baik di perkotaan maupun di perdesaan. Namun seiring dengan perkembangan kebutuhan masyarakat muslim, kini banyak bermunculan format pendidikan keagamaan yang diselenggarakan oleh masyarakat di luar pesantren dan madrasah diniyah. Di antaranya adalah munculnya lembaga pendidikan masyarakat dengan branding rumah tahfizh dan kuttab.

\section{Rumah tahfizh sudah banyak} bermunculan di beberapa wilayah di Indonesia. Salah satunya adalah Rumah Tahfizh Daarul Quran yang lekat dengan sosok Ustaz muda KH. Yusuf Mansur. Rumah tahfizh ini merupakan program yang digagas oleh Pesantren Tahfizh Daarul Qur'an, yang mengembangkan sentra-sentra tahfizh di lingkungan masyarakat dan perusahaan (Tentang Rumah Tahfidz, 2020). Selain Yusuf Mansur, Jody Brotosuseno, pendiri Waroeng Steak \& Shake juga menggagas pendirian rumah tahfizh, yang tidak hanya diperuntukkan bagi anak usia TK dan SD, melainkan juga untuk kalangan mahasiswa. Tujuan pendirian rumah tahfizh ini adalah untuk melahirkan para pemimpin yang hafal Alquran, jujur, dan tidak korupsi. Di rumah tahfizh milik Jody ini, selain menekankan pada penghafalan Alquran, juga ada pemberian ekstrakurikuler, seperti musik dan kursus enterpreneur (Beatrix, et al, 2014). Bahkan rumah tahfizh yang ia dirikan sudah mencapai empat lembaga dengan santri mukim mencapai 83 anak dan santri kalong mencapai 60 anak (Putra, 2012). Masih banyak lagi rumah tahfizh yang saat ini sudah tumbuh menjamur di berbagai wilayah di Indonesia.

Selain rumah tahfizh, lembaga pendidikan berbasis masyarakat yang kini mulai booming di Indonesia adalah kuttab. Sebenarnya, kuttab lahir sebelum datangnya Islam (Daulay and Pasa, 2016), yaitu sejak zaman jahiliyyah, namun keberadaan kuttab belum begitu dikenal (Batubara and Ariani, 2016). Sedangkan pada zaman Nabi Muhammad, kuttab mulai dikenal pasca terjadinya Perang Badar (Fathurrahman, 2017). Di Indonesia sendiri, lembaga kuttab sudah banyak bermunculan, yang keberadaannya sudah menghiasi beranda dunia maya manakala kita melakukan penelusuran internet dengan kata kunci "kuttab di Indonesia". Di antara lembaga kuttab yang ada di Indonesia adalah Kuttab Al-Fatih, Kuttab Ummul Quro, Kuttab Sahabat Quran, Kuttab Ibnu Abbas, dan lainnya. Bahkan Kuttab AlFatih yang mengusung jargon "Gemilang di Usia Belia" ini sudah membuka 25 cabang di 22 kota di Indonesia (Kuttab Al-Fatih, 2020).

Kuttab yang merupakan pendidikan nonformal berbasis tradisi keilmuan Islam klasik ini menjadi model pendidikan alternatif yang keberadaanya sangat diminati masyarakat, khususnya kelas menengah ke atas (ElBantanie, 2018). Di Jawa Tengah misalnya, lembaga kuttab sudah mulai bermunculan mengikuti trend perkembangan kuttab di Indonesia. Di antara kuttab yang hadir di Jawa Tengah adalah Kuttab AL-Fatih (Purwokerto, Tegal, Semarang), Kuttab Ibnu Abbas (Klaten, Surakarta), Kuttab Al Jazary (Surakarta), Kuttab Alhusnayain (Klaten), dan sebagainya.

Sebagai lembaga pendidikan nonformal, keberadaan kuttab belum secara eksplisit terakomodir di dalam regulasi yang berkaitan dengan pendidikan agama dan keagamaan. Istilah kuttab sendiri tidak ada di dalam regulasi, baik undang-undang maupun regulasi turunannya. Oleh karena itu, keberadaan kuttab masih belum bisa mendapatkan legalitas secara 
utuh dan menyeluruh. Dalam tataran praktis, legalitas kuttab diperoleh dalam bentuk Pusat Kegiatan Belajar Masyarakat (PKBM) di bawah naungan Dinas Pendidikan, di mana penyelenggaraan ujian berbentuk kejar paket A. Contoh kuttab yang sudah mengantongi legalitas sebagai PKBM adalah Kuttab Al-Fatih dan Kuttab Ibnu Abbas Klaten dan Surakarta.

Selain itu, ada pula kuttab yang legalitasnya berada di bawah Kementerian Agama, dengan mendaftarkan diri sebagai pendidikan kesetaraan tingkat ula. Legalitas ini bisa diperoleh jika kuttab tersebut merupakan program dari pondok pesantren. Kuttab yang memiliki legalitas pendidikan kesetaraan tingkat ula adalah Kuttab Al Jazary yang berlokasi di Surakarta.

Lantas, seperti apa dan bagaimana sebenarnya sistem pendidikan klasik yang diterapkan di lembaga kuttab masa kini? Penelitian ini bertujuan untuk mendeskripsikan penyelenggaraan bagaimana representasi pendidikan Islam klasik pada Kuttab Al Jazary Surakarta. Kuttab Al Jazary sendiri cukup menarik untuk dikaji mengingat kuttab ini cukup berbeda dengan kuttab-kuttab pada umumnya. Selain secara legal formal ia berada di bawah Kementerian Agama, kuttab ini juga memiliki kebijakan kurikulum yang berbeda dengan kuttab lain yang pada umumnya mengacu pada kurikulum Kuttab Al-Fatih.

\section{Sistem Pendidikan Islam di Indoensia}

Sistem pendidikan Islam di Indonesia sudah berkembang sejak pertama kali Islam masuk ke Indonesia (Daulay, 2012). Lembaga pendidikan Islam yang sudah ada sejak dulu dan merupakan representasi dari sistem pendidikan Islam di Indonesia adalah pesantren dan madrasah. Dalam sejarah perkembangannya, pesantren merupakan "nenek moyang" sistem pendidikan Islam yang memiliki peran yang sangat besar dalam perjalanan pendidikan Islam di Indonesia (Rouf, 2016). Pada mulanya, pondok pesantren difungsikan sebagai media Islamisasi yang memadukan tiga unsur, yaitu ibadah, tabligh, dan ilmu serta amal. Namun kini, pesantren di Indonesia sudah mengalami transformasi sebagai lembaga yang menanamkan akhlak mulia, pendidikan karakter, dan menerapkan kurikulum pemerintah (Rahman, 2018).

Selain pesantren, sistem pendidikan Islam yang sudah lama berkembang di Indonesia ditandai dengan keberadaan madrasah. Berangkat dari ketidakpuasan masyarakat Islam terhadap sistem pendidikan pesantren yang hanya menitikberatkan pada pelajaran agama, madrasah berdiri dengan menawarkan sistem pendidikan yang berimbang antara ilmu agama dan ilmu umum. Model pembelajaran madrasah merupakan perpaduan antara sistem pesantren dengan sistem (Mahpuddin Noor dalam Zuhdi, 2012). Dalam sistem pendidikan nasional, madrasah mulai menjadi bagian integral dari sistem pendidikan nasional dengan terbitnya Undang-undang No. 2 Tahun 1989 tentang Sistem Pendidikan Nasional. Dengan demikian, eksistensi, fungsi, dan peran madrasah secara nasional makin diakui (Nata, 2003).

Sistem pendidikan Islam diakui keberadaannya dalam sistem pendidikan nasional di Indonesia. Dalam Undang-undang No. 20 Tahun 2003, setidaknya ada tiga hal yang menempatkan pendidikan Islam sebagai bagian integral dalam sistem pendidikan nasional. Pertama, pendidikan Islam sebagai lembaga, dengan diakuinya keberadaan madrasah, diniyah, dan pesantren sebagai lembaga pendidikan agama dan keagamaan. Kedua, pendidikan Islam sebagai mata pelajaran, dimana pendidikan agama Islam diakui sebagai mata pelajaran wajib dalam struktur kurikulum nasional. Ketiga, pendidikan Islam sebagai nilai (value), yaitu dengan internalisasi nilai-nilai Islam dalam sistem pendidikan nasional (Daulay, 2012).

\section{Kuttab sebagai Model Pendidikan Islam Klasik}

Kuttab atau maktab berasal dari kata kataba yang berati menulis, sedangkan kuttab atau maktab berarti tempat untuk menulis atau tempat berlangsungnya kegiatan tulis menulis (Fahruddin, 2010; Chaer, 2015; Ramadhan, 2019). Dalam perkembangannya, kuttab tidak hanya difungsikan sebagai tempat belajar menulis saja, melainkan juga tempat menghafal Alquran dan mengajarkan keterampilan membaca dan menulis (Masyhuri, 2007). Kuttab pada dasarnya adalah sebuah tempat 
untuk belajar dan menulis bagi anak-anak (Syarifuddin, 2004; Makdisi, 2005; Daulay and Pasa, 2016; Mahasnah, 2016; Fathurrahman, 2017). Penyelenggaraan kuttab biasanya dilakukan di rumah-rumah guru (Idi, 2015; Batubara and Ariani, 2016; Fathurrahman, 2017). Keberadaan kuttab menunjukkan bahwa Islam memiliki perhatian yang besar terhadap pendidikan anak usia dini dan pendidikan dasar, dengan pertimbangan bahwa pendidikan masa kanak-kanak akan menentukan keberhasilan pendidikan di masa selanjutnya (Nata, 2010).

Kuttab merupakan lembaga pendidikan yang sudah ada sejak zaman sebelum Islam (Siroj, 2006; Batubara and Ariani, 2016; Daulay and Pasa, 2016; Mahasnah, 2016; Ramadhan, 2019), bahkan lembaga pendidikan dasar tertua yang pernah ada (Idi, 2015). Meskipun sudah ada sebelum lahirnya Islam di Arab, namun perkembangan kuttab masih belum begitu pesat karena masyarakat Arab yang memasukkan anaknya di kuttab masih sedikit (Daulay and Pasa, 2016). Menurut Shalaby, terdapat dua jenis kuttab, yaitu kuttab yang mengajarkan membaca dan menulis dan kuttab yang mengajarkan Alquran dan dasar-dasar agama (Shalaby dalam Daulay and Pasa, 2016).

Setelah datangnya Islam, kuttab menjadi tempat pendidikan yang utama bagi anak-anak. Tidak ada ketentuan batasan umur bagi anakanak yang masuk ke kuttab pada saat itu. Namun kebanyakan orang tua memasukkan anaknya ke kuttab pada rentang umur antara 57 tahun (Mahasnah, 2016). Sejak awal abad Islam, anak-anak yang menuntut ilmu di kuttab berasal dari berbagai lapisan sosial ekonomi, baik anak-anak dari orang yang merdeka maupun budak (Makdisi, 2005). Setelah datangnya Islam, kuttab mengalami perkembangan yang pesat sehingga kuttab menjadi dasar pembelajaran membaca dan menulis Alquran serta pengembangan pengetahuan agama (Ramadhan, 2019).

Sejarah pendidikan Islam klasik membuktikan bahwa kuttab merupakan lembaga pendidikan tingkat dasar yang eksistensinya mengalami masa gemilang pada awal penyebaran agama Islam. Pada era tersebut, kuttab merupakan tempat pertama seorang anak belajar membaca dan menulis Alquran. Tidak hanya itu, kuttab juga mengajarkan anak tentang prinsip-prinsip agama, bahasa dan ilmu hitung (Hidayat, 2017). Meski pernah mengalami masa gemilang, keberadaan kuttab mulai tergeser dengan sistem pendidikan modern (Saputri, 2017) hingga istilah kuttab mulai redup dan menghilang dalam dunia pendidikan Islam.

\section{Dinamika Kuttab di Indonesia}

Di Indonesia, kuttab merupakan lembaga pendidikan nonformal yang muncul pada tahun 2012, yang ditandai dengan berdirinya Kuttab Al-Fatih di Depok. Jika menelusuri perjalanan panjang sejarah pendidikan Islam di Indonesia, lembaga pendidikan nonformal sudah lahir sejak zaman dahulu, ditandai dengan berdirinya nggon ngaji, yaitu tempat siswa belajar Alquran (Dhofier dalam Fahruddin, 2010). Nggon ngaji terbatas pada pembelajaran membaca dan menulis huruf Arab dan membaca Alquran, sedangkan jika ingin belajar lebih lanjut tentang fikih, tafsir, dan tarikh bisa melanjutkan ke pesantren (Hasbullah dalam Fahruddin, 2010). Jika dilihat dari materi pembelajaran yang menekankan pada ranah membaca dan menulis Alquran dengan segmentasi anak-anak, maka ada unsur kesamaan antara nggon ngaji dengan kuttab (Fahruddin, 2010).

Munculnya lembaga kuttab di Indonesia dipelopori oleh Budi Ashari, seorang alumni Fakultas Hadis Universitas Islam Madinah. Ia menggagas sebuah lembaga pendidikan Kuttab Al-Fatih pada tahun 2012, sebuah model pendidikan alternatif di luar sekolah. Menurutnya, lembaga kuttab merupakan lembaga pendidikan yang sudah ada pada zaman nabi dan telah sukses melahirkan generasi berkapasitas luar biasa di usia belia (Hidayat, 2017). Kedudukan Kuttab Al-Fatih adalah sebagai lembaga pendidikan nonformal dengan lisensi dari Pusat Kegiatan Belajar Masyarakat (PKBM). Dengan demikian eksistensi lembaga Kuttab Al-Fatih dapat dianggap setara dengan pesantren atau madrasah meski dengan model pendidikan yang berbeda (Yaman and Gultom, 2017).

Keberadaan lembaga kuttab yang mulai ramai bermunculan tidak dipungkiri berawal dari berdirinya Kuttab Al-Fatih pada tahun 2012. Bahkan dalam kurun waktu yang relatif singkat, Kuttab Al-Fatih mampu 
mengembangkan sayap hingga di 22 kota besar di Indonesia, dengan jumlah lembaga mencapai 25 lembaga kuttab yang berpusat di Depok Jawa Barat (Kuttab Al-Fatih, 2020). Pesatnya perkembangan lembaga kuttab ini menandakan keberadaannya begitu diterima oleh masyarakat Indonesia dengan model pendidikan yang berbasis Alquran.

Meski sarat dengan muatan agama, lembaga kuttab belum secara eksplisit terakomodir dalam regulasi yang mengatur tentang pendidikan agama dan keagamaan. Jika dilihat dari karakteristik kuttab yang berkembang di Indonesia, sistem pendidikan kuttab mirip dengan penyelenggaraan pendidikan di madrasah dan pesantren, yaitu adanya penekanan pada materi Alquran dan dasar-dasar agama. Namun demikian, ada beberapa perbedaan yang cukup mendasar antara madrasah, pesantren, dan kuttab, yang disajikan pada Tabel 1 (Hidayat, 2017).

Tabel 1. Perbandingan madrasah, pesantren, dan kuttab

\begin{tabular}{|c|c|c|c|}
\hline Aspek & Madrasah & Pesantren & Kuttab \\
\hline Usia & 6-12 tahun & Bebas & 5-12 tahun \\
\hline Status & Formal & Non Formal & Non Formal \\
\hline Durasi pendidikan & 6 tahun & $\begin{array}{l}\text { Menyesuikan } \\
\text { kebutuhan }\end{array}$ & 7 tahun \\
\hline Jenjang & Kelas 1, 2, 3, 4, 5, 6 & Kondisional & $\begin{array}{l}\text { Kuttab awal ( } 3 \text { tahun) dan } \\
\text { kuttab qonuni ( } 4 \text { tahun) }\end{array}$ \\
\hline Kurikulum & $\begin{array}{l}\text { Mengacu pada } \\
\text { kurikulum } \\
\text { Kementerian Agama }\end{array}$ & Berbasis kitab klasik & $\begin{array}{l}\text { Mengembangkan } \\
\text { kurikulum mandiri }\end{array}$ \\
\hline Kualifikasi guru & $\begin{array}{l}\text { Bergelar minimal } \\
\text { sarjana }\end{array}$ & $\begin{array}{l}\text { Alumni pondok } \\
\text { pesantren, menguasi } \\
\text { nahwu, sharaf, dan } \\
\text { kitab klasik }\end{array}$ & $\begin{array}{l}\text { Memiliki kompetensi } \\
\text { dalam tahfizh quran, } \\
\text { kesamaan dalam hal } \\
\text { ideologi keagamaan }\end{array}$ \\
\hline
\end{tabular}

Sumber: (Hidayat, 2017)

Dilihat dari aspek legal formal, Kuttab AlFatih memiliki legalitas lembaga di bawah PKBM, yang secara struktur berada di bawah wewenang Kementerian Pendidikan dan Kebudayaan. Jalur ini banyak diikuti oleh kuttab-kuttab lain, seperti Kuttab Ibnu Abbas di Klaten dan Surakarta. Berbeda dengan Kuttab Al-Fatih dan Kuttab Ibnu Abbas, eksistensi Kuttab Al Jazary Surakarta secara legal formal merupakan pendidikan kesetaraan tingkat ula di bawah wewenang Kementerian Agama. Tidak ada kendala bagi Kuttab Al Jazary untuk mendaftarkan lembaganya di Kementerian Agama karena keberadaannya sebagai madrasah salafiyah ula yang merupakan salah satu program pendidikan dari Pondok Pesantren Jajar Surakarta. Istilah kuttab sendiri dipilih dengan tujuan mengenalkan kepada masyarakat tentang lembaga kuttab yang merupakan bagian dari pendidikan Islam Klasik pada awal perkembangan Islam. Selain itu, penamaan kuttab juga didasarkan pada kurikulum yang berbeda dengan kurikulum madrasah pada umumnya, di mana Kuttab Al Jazary lebih menekankan kepada kurikulum Alquran dengan target hafalan minimal 24 juz selama enam tahun.

\section{KAJIAN TEORI}

Seiring dengan dinamika kuttab yang mulai tumbuh dan berkembang di Indonesia, cukup banyak literatur yang mengkaji tentang lembaga kuttab. Beberapa kajian memberikan referensi tentang bagaimana eksistensi kuttab di masa lampau sebagai lembaga pendidikan klasik yang telah ada pada awal perkembangan Islam (Fahruddin, 2010; Chaer, 2015; Batubara and Ariani, 2016; Fathurrahman, 2017; Muspiroh, 2019). Kelima hasil penelitian tersebut memaparkan perkembangan kuttab pada awal munculnya Islam di negeri Arab, bahkan beberapa kajian menyebutkan bahwa kuttab sudah ada sejak sebelum Islam dan berkembang pesat pasca kedatangan Islam. Fathurrahman (2017) lebih banyak memaparkan sejarah pendidikan Islam pada 
awal perkembangan Islam yang secara umum bersifat informal dan dilaksanakan dalam rangka penyebaran agama Islam. Pendidikan Islam saat itu banyak dilakukan di rumah-rumah sahabat yang selanjutnya mengalami pergeseran dengan menjadikan masjid sebagai lembaga pendidikan Islam. Selain masjid, bagian sejarah pendidikan Islam klasik pada masa itu adalah kuttab, yang merupakan pendidikan dasar bagi anak-anak.

Sedikit berbeda dengan Fathurrahman (2017), penelitian yang dilakukan oleh Chaer, 2015; Batubara and Ariani, 2016; Muspiroh, 2019 mengkhususkan kajiannya kepada lembaga kuttab dalam tinjauan sejarah. Mereka menjelaskan bagaimana sejarah kuttab yang sebenarnya sudah ada sejak zaman pra Islam. Dalam tulisannya, mereka menyebutkan bahwa ada dua karakteristik kuttab pada zaman dahulu, yaitu kuttab yang difungsikan sebagai tempat belajar membaca dan menulis dan kuttab sebagai tempat pendidikan yang mengajarkan Alquran dan dasar-dasar keagamaan. Chaer (2015) juga memaparkan metode pembelajaran yang diterapkan pada kuttab pada masa lampau, yang secara umum menggunakan metode halaqah, tanya jawab, imla, dan hafalan. Sementara Batubara and Ariani (2016) sedikit memaparkan tentang materi kuttab yang berasal dari puisi dan pepatah Arab yang berisi tentang tradisi-tradisi yang baik. Hampir sama dengan Chaer, Fahruddin (2010) juga mengkaji Kuttab dalam tinjauan sejarah, hanya saja ia lebih memfokuskan tulisannya pada kuttab di era Bani Umayyah.

Kajian tentang kuttab di Indonesia dapat ditemukan dari beberapa hasil penelitian yang lebih banyak mengambil Kuttab Al Fatih sebagai fokus kajian (Putranto, 2016; Hidayat, 2017; Ulwiyah, Maftuhatin and Samsukadi, 2018). Hal ini sangat wajar mengingat perkembangan Kuttab Al Fatih yang sangat pesat yang hingga saat ini sudah berdiri di 22 kota di Indonesia. Tulisan Hidayat (2017) mengkaji Kuttab Al Fatih Purwokerto dari aspek orientasi ideologi, dimana hasil penelitiannya menyebutkan bahwa Kuttab Al Fatih Purwokerto memiliki ideologi konservatif-fundamentalis-religius. Ulwiyah, Maftuhatin and Samsukadi (2018) lebih tertarik melakukan kajian pendidikan karakter Islam yang diterapkan di Kuttab Al Fatih Jombang. Tulisannya memberikan informasi bahwa Kuttab Al Fatih Jombang memberikan materi Alquran dan iman yang diterapkan dengan dua pola, yaitu pola pembentukan dan pola pembiasaan sehingga karakter Islam dapat terinternalisasi secara alami. Sementara Putranto (2016) mengkaji Kuttab Al Fatih Malang ditinjau dari sistem pendidikannya, yang mencakup tujuan pendidikan, kurikulum, pendekatan dan metode, serta evaluasi.

Berbeda dengan beberapa kajian kuttab sebelumnya, tulisan ini bertujuan untuk mendeskripsikan sistem pendidikan Kuttab Al Jazary Surakarta yang merepresentasikan model pendidikan Islam Klasik. Selain karena belum adanya kajian tentang Kuttab Al Jazary Surakarta, tulisan ini menjadi menarik karena menampilkan karakteristik dari Kuttab AL Jazary, yang secara legal formal dan kurikulum cukup berbeda dengan Kuttab Al Fatih.

\section{METODOLOGI}

Penelitian ini merupakan penelitian kualitatif dengan metode studi kasus. Pendekatan studi kasus dilakukan untuk melakukan kajian secara rinci, mendalam, dan menyeluruh terhadap obyek penelitian dalam kurun waktu tertentu (Umar, 2003). Sebagai penelitian studi kasus, penulis fokus pada satu lembaga pendidikan saja, yaitu Kuttab Al Jazary Surakarta, yang secara umum memiliki karakteristik berbeda dengan Kuttab lainnya di Indonesia. Pengumpulan data dilakukan melalui wawancara, dokumentasi, dan observasi. Data yang diperoleh melalui ketiga teknik pengumpulan data tersebut selanjutnya dilakukan kategorisasi dan analisis data dengan memperhatikan kaidah keabsahan data kualitatif.

Pemeriksaan keabsahan data dilakukan dengan melakukan perpanjangan pengamatan dan triangulasi, baik triangulasi sumber, teknik pengumpulan data, maupun triangulasi waktu. Perpanjangan pengamatan dilakukan dengan pengamatan yang tidak hanya satu kali, melainkan beberapa kali untuk memperoleh data yang valid. Triangulasi sumber dilakukan dengan pengecekan data kepada sumbersumber yang berbeda, baik dari unsur pengelola kuttab, pengelola yayasan, dan stakeholder. 
Triangulasi teknik berupa pengecekan data yang diperoleh dari teknik yang berbeda, baik teknik wawancara, pengamatan, ataupun dokumentasi sehingga dihasilkan data yang cukup valid. Sementara triangulasi waktu dilakukan dengan menggali data di waktuwaktu yang berbeda.

Analisis data yang digunakan adalah analisis deskriptif dan eksplorasi. Hal ini mengingat metode yang digunakan pada penelitian ini lebih mendekati kepada metode studi kasus deskriptif yang eksploratoris dan deskriptif, yaitu pendekatan studi kasus yang dilakukan untuk menjawab pertanyaan "apa" atau "what" (Suwendra, 2018). Sebagai penelitian studi kasus, analisis data dilakukan dengan membangun deskripsi secara rinci dan mendalam serta melakukan interpretasi terhadap data terkait apa dan bagaimana profil dan sistem pendidikan di Kuttab Al Jazary Surakarta, serta mengaitkannya dengan model pendidikan Islam klasik.

\section{HASIL DAN PEMBAHASAN}

\section{Mengenal Kuttab Al Jazary}

Kuttab Al Jazary berada di Gang Delima VII No. 15 Jajar Laweyan Surakarta. Lokasinya berada tidak jauh dari Masjid Jajar yang sekaligus merupakan pusat administrasi lembaga pendidikan Pondok Pesantren Jajar Surakarta. Kuttab Al Jazary Surakarta berada di bawah Yayasan Masjid Jajar Surakarta, berdasarkan Akte Notaris no. 07 Mei 2016 dan SK Kemenkumham RI AHU-0025928.01.04 Tahun 2016.

Jauh sebelum terbentuknya Yayasan Masjid Jajar Surakarta, keberadaan Masjid Jajar yang dibangun sekitar tahun 1950-an ini pernah menjadi pusat kegiatan dakwah dari berbagai ormas keagamaan, mulai dari NU, Muhammadiyah, MTA, dan lainnya. Keberadaan Masjid Jajar yang terletak tepat di jalur strategis ini membuatnya ramai dikunjungi oleh jamaah Muslim dari berbagai latar belakang organisasi. Namun kejayaan ini sempat mengalami masa surut sekitar tahun 2002, dimana Masjid Jajar mulai ditinggalkan oleh jamaahnya (UT, wawancara, 4 Desember 2019).
Setelah beberapa tahun sepi dari jamaah, datanglah Ustaz Taufan yang pada saat itu masih menyandang status sebagai mahasiswa UNS, bersama beberapa teman merintis sebuah kegiatan ma'had ilmi. Kegiatan utama dari ma'had ilmi ini adalah melakukan kajian keislaman, yang diikuti oleh mahasiswa dari UNS, UMS, dan perguruan tinggi lain di Surakarta dan sekitarnya. Seiring perjalanan dan tuntutan kebutuhan masyarakat Muslim, ma'had ilmi berkembang menjadi sebuah yayasan yang secara legal formal telah berbadan hukum dengan nama Yayasan Masjid Jajar Surakarta (UT, wawancara, 4 Desember 2019). Setelah memperoleh legalitas sebagai badan hukum pada tahun 2016, satu tahun setelahnya Yayasan Masjid Jajar mendaftarkan Pondok Pesantren Masjid Jajar dan memperoleh pengakuan terdaftar dari Kementerian Agama sebagai Penyelenggara Program Wajib Belajar Pendidikan Dasar.

Yayasan Masjid Jajar Surakarta merupakan lembaga yang berorientasi pada kegiatan dakwah Islam, sosial, dan pendidikan Islam, yang berlandaskan Alquran dan Assunnah menurut pemahaman salafush shalih. Di bidang pendidikan, Yayasan Masjid Jajar memiliki lima program pendidikan yang dikelola, yaitu Kuttab Al Jazary (setingkat SD), Madrasah Qur'an Al Mutawassithoh (MQW) setingkat SMP, Kulliyatul Mu'alimin Al Islamiyah (KMI) setingkat SMA, Ma'had 'Aly Bahasa Arab dan Pendidikan Islam (Mabais) yang berijazah negara setingkat $\mathrm{S}-1$, dan Madrasah Diniyah Tingkat Ulya.

Pendirian Kuttab Al Jazary digagas oleh Ustaz Taufan, Ustaz Rosyad Nur Ilyas beserta isterinya, Ummu Ahnaf. Meski secara legal formal bernama madrasah salafiyyah ula, penamaan kuttab sengaja dipilih untuk menarik minat masyarakat dengan menawarkan sistem pendidikan yang menekankan kepada hafalan Alquran. Sementara Al Jazary diambil dari nama Syeikh Imam Al Jazary, ahli di bidang qiroah, tilawah, dan tajwid. Beliau menyusun matan tajwid yang sangat terkenal yang biasa dipakai oleh para tholabul ilmi para penghafal Alquran (UA, wawancara, 3 Desember 2019).

Kedudukan Kuttab Al Jazary sebagai madrasah salafiyyah ula yang memiliki legalitas pendidikan kesetaraan tingkat ula 
diakui memberikan poin lebih dibanding kuttab lain yang belum memiliki legalitas kelembagaan. Masyarakat Muslim di Surakarta yang tertarik untuk menyekolahkan anaknya ke kuttab lebih memilih Kuttab Al Jazary dibanding kuttab lainnya, dengan pertimbangan legalitas yang dimiliki (UA, wawancara, 3 Desember 2019). Hal ini mengingat bahwa selain Kuttab Al Jazary yang sudah terdaftar di Kementerian Agama, hanya ada satu kuttab yang sudah mendaftarkan dirinya ke PKBM di bawah Dinas Pendidikan Kota Surakarta, yaitu Kuttab Ibnu Abbas (I, wawancara, 2 Desember 2019).

\section{Pengembangan Kurikulum pada Kuttab Al Jazary}

Sebagai lembaga pendidikan yang berbasis Alquran, Kuttab Al Jazary yang menjadikan amal qurany dan quran amaly sebagai motto ini memiliki visi 'menjadi generasi penghafal Alquran di usia dini yang bertakwa dan ber-akhlaqul karimah, sesuai manhaj salafus sholih'. Sebagai lembaga pendidikan yang setara dengan sekolah dasar (SD/MI), Kuttab Al Jazary menyelenggarakan pendidikan bagi anak usia 6 hingga 12 tahun. Penekanan materi pada hafalan Alquran

Tabel 2. Kurikulum Kuttab Al Jazary mengacu pada pemahaman bahwa rentang waktu usia 6 hingga 15 tahun adalah usia emas bagi setiap anak untuk menghafal Alquran. Bahkan banyak ulama seperti Imam Malik, Imam Syafi'i, Imam Bukhari, Imam Muslim, Sulthan Muhammad Al Fatih yang hafal Alquran sebelum baligh (Kuttab Al Jazary, 2019).

Tidak ada syarat khusus yang diberlakukan oleh Kuttab Al Jazary bagi calon santri, bahkan Kuttab Al Jazary yang berhaluan salafi ini tidak hanya menerima siswa dari masyarakat salafi saja, melainkan terbuka untuk semua kalangan Muslim. Seleksi bagi para calon santri meliputi tes membaca Alquran dan tes kemandirian. Meski masih berusia rata-rata 6 tahun, tes seleksi baca Alquran tidak menemukan kendala berarti mengingat hampir semua calon santri merupakan lulusan TK Islam Terpadu (IT). Selain tes membaca Alquran, calon santri juga akan dites kecepatan menghafal Alquran, dengan memberikan satu surat yang belum pernah dihafal sebelumnya untuk dihafal di rumah bersama orang tua. Tes ini bertujuan untuk mengetahui kemampuan dan kecepatan menghafal dari calon santri (UA, wawancara, 6 Desember 2019).

\begin{tabular}{|c|c|c|c|c|c|c|c|}
\hline \multirow{2}{*}{ Jenis } & \multirow{2}{*}{ Komponen } & \multicolumn{6}{|c|}{ Tahun dan alokasi waktu perpekan } \\
\hline & & $\mathrm{I}$ & II & III & IV & $\mathrm{V}$ & $\mathrm{VI}$ \\
\hline \multirow{2}{*}{ Alquran } & Tahsin/iqro & 6 & 6 & 2 & 1 & 1 & 1 \\
\hline & Tahfizh & 28 & 28 & 28 & 32 & 32 & 32 \\
\hline \multirow{4}{*}{ Syar’i } & Aqidah & 2 & 2 & 2 & 1 & 1 & 1 \\
\hline & Fiqih & - & - & 1 & 1 & 1 & 1 \\
\hline & Bahasa arab & - & - & 1 & 1 & 1 & 1 \\
\hline & Hadis & - & - & 1 & 1 & 1 & 1 \\
\hline \multirow{6}{*}{ Umum } & Hisab & 3 & 3 & 3 & 2 & 2 & 2 \\
\hline & Olah raga & 2 & 2 & 2 & 2 & 2 & 2 \\
\hline & Bahasa Indonesia & 5 & 5 & 3 & 3 & 3 & 3 \\
\hline & $\mathrm{PKn}$ & - & - & 1 & 1 & 1 & 1 \\
\hline & IPA & - & - & 1 & 1 & 1 & 1 \\
\hline & IPS & - & - & 1 & 1 & 1 & 1 \\
\hline \multirow{2}{*}{ Mulok } & Kitabah & 1 & 1 & 1 & 1 & 1 & 1 \\
\hline & Bahasa jawa & 1 & 1 & 1 & & & \\
\hline Total & & 48 & 48 & 48 & 48 & 48 & 48 \\
\hline
\end{tabular}

Sumber: (Profil Kuttab Al Jazary, 2019)

Sebagai lembaga pendidikan yang baru berdiri, Kuttab Al Jazary baru memiliki satu jenjang kelas, yaitu kelas I, dengan jumlah

santri sebanyak 18 anak, terdiri dari 10 santri putra dan 8 santri putri. Meskipun baru memiliki satu kelas, Kuttab Al Jazary telah 
menyusun kurikulum untuk program pembelajaran selama enam tahun ke depan. Kurikulum yang disusun Kuttab Al Jazary cukup berbeda dengan kurikulum kuttab di Indonesia yang pada umumnya mengacu pada Kuttab al Fatih. Kurikulum utama yang dikembangkan Kuttab Al Fatih adalah "adab dan iman”, sedangkan Kuttab Al Jazary lebih menekankan tahfizh dengan tidak meninggalkan pelajaran umum. Kurikulum yang dikembangkan Kuttab Al Jazary dapat dilihat pada Tabel 2.

Tabel 2 menunjukkan bahwa kurikulum Kuttab Al Jazary sebagian besar berisi pembelajaran tahfizh Alquran. Namun sebagai lembaga yang memperoleh legalitas program

Tabel 3. Jadwal Pelajaran Kuttab Al Jazary pendidikan kesetaraan tingkat ula, Kuttab Al Jazary juga menyelenggarakan pembelajaran ilmu syar'i (Aqidah, Fiqih, Bahasa Arab, dan Hadis) dan ilmu umum (Hisab/Matematika, Olah Raga, Bahasa Indonesia, IPA, dan IPS). Selain itu, Kuttab Al Jazary menambahkan Kitabah dan Bahasa Jawa sebagai mata pelajaran dalam rumpun muatan lokal (mulok).

Kegiatan belajar mengajar di Kuttab Al Jazary berlangsung 48 jam pelajaran setiap minggu, dengan alokasi tiap jam pelajaran adalah 35 menit. Kegiatan pembelajaran dimulai pada jam 07.00 dan berakhir pada jam 15.30 WIB. Adapun jadwal pelajaran di Kuttab Al Jazary disajikan pada Tabel 3.

\begin{tabular}{|c|c|c|}
\hline Waktu & Jam & Kegiatan \\
\hline $07.00-07.35$ & 1 & Tahsin/Iqro \\
\hline $07.35-08.10$ & 2 & Tahfidz \\
\hline $08.10-08.45$ & 3 & Tahfidz \\
\hline $08.45-09.20$ & 4 & Tahfidz \\
\hline $09.20-09.45$ & \multicolumn{2}{|c|}{ Istirahat (Salat Duha) } \\
\hline $09.45-10.20$ & 5 & KBM mapel Syari/Umum \\
\hline $10.20-10.55$ & 6 & KBM mapel Syari/Umum \\
\hline $10.55-11.30$ & 7 & KBM mapel Syari/Umum \\
\hline $11.30-12.15$ & \multicolumn{2}{|c|}{ Sholat dhuhur, makan siang } \\
\hline $12.15-12.50$ & 8 & Tahfidz \\
\hline $12.50-13.25$ & 9 & Tahfidz \\
\hline $13.25-14.45$ & \multirow{2}{*}{\multicolumn{2}{|c|}{$\begin{array}{l}\text { Qoilulah (istirahat tidur siang) } \\
\text { Sholat ashar, hafalan doa/hadits, pulang }\end{array}$}} \\
\hline $14.45-15.30$ & & \\
\hline
\end{tabular}

Sumber: (Profil Kuttab Al Jazary, 2019)

\section{Sistem Pendidikan di Kuttab Al Jazary}

Ada tiga pendidikan utama yang menjadi pilar penyelenggaraan pembelajaran di Kuttab Al Jazary, yaitu pendidikan Alquran, pendidikan adab, dan pendidikan ilmu.

Pendidikan Alquran merupakan pendidikan utama di Kuttab Al Jazary dan mendominasi kurikulum yang dikembangkan hingga mencapai $70 \%$ dari total kegiatan belajar mengajar. Santri Kuttab Al Jazary ditargetkan bisa menghafal 30 juz (maksimal) dalam waktu enam tahun pembelajaran, atau minimal 24 juz. Mengingat usia santri pada awal masuk masih relatif kecil dan tidak semua santri baru bisa membaca Alquran, pengajar Kuttab Al Jazary menerapkan metode pembelajaran talaqqi (UA, wawancara, 6 Desember 2019). Metode talaqqi sendiri berarti metode pengajaran Alquran, dimana asatizh yang merupakah hafizh/hafizhah berhadap-hadapan secara langsung dan individual dengan santri untuk memperdengarkan Alquran (Qawi, 2017).

Sebagai upaya untuk mencetak generasi Islam yang mampu menghafal Alquran secara baik dan lancar, Kuttab Al Jazary memberlakukan persyaratan khusus bagi ustaz dan ustazah yang mengajar di lembaga ini. Selain memiliki ketaatan beragama Islam, asatizh juga diharuskan memiliki hafalan minimal 10 juz untuk pengampu kelas 1 dan 2, sedangkan asatizh pengampu kelas 3 ke atas harus memiliki hafalan 30 juz. Asatizh yang mengajar di Kuttab Al Jazary juga merupakan hafizh/hafizhah yang memahami ilmu tajwid dengan baik dan benar serta memiliki komitmen untuk memajukan lembaga. 
Ada beberapa metode yang dirumuskan Kuttab Al Jazary dalam upaya mencapai target hafalan 30 juz secara mutqin (baik dan lancar) bagi para santrinya. Pertama, metode iqra dan tahsinul tilawah, yaitu metode untuk memantapkan kelancaran santri dalam membaca Alquran. Dalam tahapan ini, santri akan dibimbing membaca Alquran secara tartil dengan menerapkan ilmu tajwid yang baik dan benar. Kedua, metode qiroah, dimana santri yang sudah lulus program iqra akan dilanjutkan dengan membaca Alquran secara binnadhar dengan melihat mushaf di hadapan asatizh (Profil Kuttab Al Jazary, 2019).

Ketiga, metode Sabaq Sabqy Manzil, dimana santri mengikuti setoran hafalan baru (sabaq). Santri juga diwajibkan melakukan setoran murojaah (mengulang) hafalan baru (sabqy), serta memberikan setoran murojaah hafalan lama bagi santri yang telah memiliki hafalan lebih dari satu juz (manzil). Metode keempat adalah tasmi' Am, dimana para santri menghafal Alquran di depan seluruh pengurus, asatizh, walisantri, santri Kuttab, dan tamu undangan, dengan minimal hafalan adalah 1 juz. Kelima adalah metode tasmi' khosh, yang diadakan sebulan sekali dimana santri membacakan hafalannya di depan pengelola kuttab dan wali santri. Metode terakhir adalah hafalan Matan Al Jazary dan Tuhfatul Athfal, yang dilakukan setiap pagi (Profil Kuttab Al Jazary, 2019).

Sebagaimana di Kuttab Al Fatih, pendidikan adab menjadi salah satu poin utama dalam proses belajar santri di kelas, lingkungan kuttab, dan keluarga (Ulwiyah, Lilik Maftuhatin dan Mochamad Samsukadi, 2018), Kuttab Al Jazary juga menerapkan pentingnya pendidikan adab bagi para santri. Pendidikan adab yang ditekankan kepada para santri di antaranya pembiasaan untuk berdoa, salat duha, salat zuhur dan asar berjamaah, senyum sapa salam, dan pembiasaan santri mengucapkan ungkapan syar' $i$ seperti alhamdulillah, masya Allah, insya Allah, dan sebagainya. Selain pendidikan adab di kelas dan lingkungan kuttab, asatizh juga melakukan pemantauan adab santri di lingkungan keluarga melalui buku pantauan adab yang diisi dan ditandatangani wali santri (Profil Kuttab Al Jazary, 2019).
Meskipun pendidikan di Kuttab Al Jazary mayoritas adalah pendidikan Alquran, namun santri di Kuttab ini juga menerima pendidikan ilmu, mencakup ilmu syar' $i$, ilmu umum, dan muatan lokal (mulok). Ilmu-ilmu syar'i meliputi mata pelajaran yang mirip dengan Kurikulum Kementerian Agama, yaitu Aqidah, Fiqih, Bahasa Arab, dan Hadis. Sedangkan ilmu umum mencakup Hisab/Matematika, Olah Raga, Bahasa Indonesia, PKn, IPA, dan IPS, serta Mulok yang mencakup Bahasa Jawa dan Kitabah (Profil Kuttab Al Jazary, 2019).

Sebagai lembaga yang berorientasi pada hafalan Alquran sekaligus mengantongi ijin operasional sebagai pendidikan kesetaraan tingkat $u l a$, Kuttab Al Jazary mengeluarkan dua ijazah bagi para santrinya, yaitu ijazah kuttab dan ijazah Kementerian Agama. Kedua ijazah ini diperoleh setelah siswa yang telah menyelesaikan studi enam tahun dan mengikuti ujian yang terdiri dari dua jenis ujian, yaitu ujian Alquran dan ujian ilmu syar'i dan ilmu umum.

Ujian Alquran terdiri dari beberapa tahapan, yaitu ikhtibar juziyy, ikhtibar manziliy, dan ujian akhir semester. Ikhtibar juziyy diberikan kepada santri yang telah menyelesaikan setoran hafalan 1 juz. Santri dinyatakan lulus ujian ikhtibar juziyyah ketika mereka bisa menyetorkan hafalannya dan menjawab pertanyaan sambung ayat secara mutqin dengan minimal kesalahan adalah 20 kali. Kelulusan ujian ikhtibar juziyy ini sekaligus menjadi syarat untuk melanjutkan hafalan ke juz selanjutnya atau mengikuti ikhtibar manziliy bagi santri yang sudah memiliki hafalan lebih dari satu juz. Ikhtibar manziliy merupakan ujian yang diberikan kepada santri untuk menghafal seluruh juz yang telah dihafal. Standar kelulusan pada tahap ini adalah ketika santri bisa menjawab pertanyaan dengan mutqin dengan minimal 10 kesalahan untuk tiap juznya. Santri dapat melanjutkan hafalan ke juz berikutnya setelah dinyatakan lulus pada ujian ikhtibar manziliy. Tahap selanjutnya adalah ujian akhir semester, dimana santri dapat mengujikan semua juz kepada ustaz/ustazah (Profil Kuttab Al Jazary, 2019).

Selain ujian Alquran, Kuttab Al Jazary juga memberikan ujian ilmu syar'i dan ilmu umum kepada para santrinya. Ujian ini lebih 
bersifat ujian formal berdasarkan ketentuan pemerintah. Oleh karena itu, pelaksanaan ujian ilmu syar'i dan umum ini mengikuti kalender akademik yang telah ditentukan oleh pemerintah, dalam hal ini Kementerian Agama.

\section{Representasi Pendidikan Islam Klasik pada Kuttab Al Jazary}

Di Indonesia, berdirinya lembaga kuttab dipelopori oleh Kuttab Al-Fatih, yang didirikan oleh Budi Ashari, Direktur Lembaga Kajian dan Studi Peradaban Islam Cahaya Siroh dan Pembina Parenting Nabawiyah. Selain sebagai penggagas berdirinya Kuttab Al Fatih, Budi Ashari juga berperan sebagai pembina Kuttab Al Fatih (Umar, 2019). Pendirian kuttab didasari rasa keinginan untuk mengembalikan kejayaan kurikulum pendidikan Islam di masa lalu yang telah terbukti banyak menghasilkan generasi-generasi pilihan (Putranto, 2016). Kuttab Al-Fatih yang berpusat di Depok ini telah berkembang dengan pesat, yang dibuktikan dengan berdirinya 25 Kuttab AlFatih cabang di 22 kota di Indonesia (Kuttab AlFatih, 2020). Keberhasilan Kuttab Al-Fatih ini menjadi inspirasi bagi masyarakat Islam untuk turut mengembangkan lembaga kuttab.

Tidak dipungkiri bahwa Kuttab Al Fatih sedikit banyak memberikan inspirasi bagi pendirian Kuttab Al Jazary. Namun demikian, dalam penyusunan kurikulum Kuttab Al Jazary cukup jauh berbeda dengan kurikulum Kuttab Al-Fatih. Kurikulum utama yang dikembangkan Kuttab Al Fatih adalah "adab dan iman", sedangkan Kuttab Al Jazary lebih menekankan tahfizh dengan tidak meninggalkan pelajaran umum. Selain itu, penjenjangan kelas yang dilakukan Kuttab Al Jazary juga berbeda dengan Kuttab Al Fatih. Penjenjangan kelas di Kuttab Al Jazary lebih mirip model penjenjangan di madrasah ibtidaiyah (MI), yaitu diawali kelas I hingga kelas VI. Sementara penjenjangan di Kuttab Al Fatih terdiri dari kuttab awal (3 tahun) dan kuttab qonuni (4 tahun) (Hidayat, 2017; Daylis, 2019).

Jalur legalitas yang ditempuh Kuttab Al Jazary juga berbeda. Kuttab Al-Fatih secara umum mendaftarkan lembaganya sebagai PKBM di bawah Dinas Pendidikan, sedangkan Kuttab Al Jazary memilih jalur berbeda, yaitu dengan mendaftarkannya sebagai Program Pendidikan Kesetaraan Tingkat Ula di bawah Kementerian Agama. Langkah ini ditempuh mengingat keberadaan kuttab belum terakomodir di dalam regulasi yang menyangkut pendidikan agama dan keagamaan (Z, wawancara, 2 Desember 2019). Sebagai program pendidikan kesetaraan tingkat ula, Kuttab Al Jazary tidak dapat mengesampingkan adanya kewajiban memberikan materi umum kepada para santrinya. Namun demikian, materi yang diberikan tetap menitikberatkan pada materi Alquran, karena target yang ingin dicapai adalah santri dapat menghafal 30 juz atau minimal 24 juz secara mutqin. Penekanan pada pembelajaran Alquran, baik membaca dan menulis inilah yang menjadikan Kuttab Al Jazary sedikit banyak telah melakukan reaktualisasi pendidikan Kuttab pada peradaban Islam klasik.

Lembaga pendidikan kuttab dalam peradaban Islam bukan merupakan istilah baru, melainkan sudah ada sejak zaman pra Islam. Kuttab sebagai lembaga pendidikan Islam klasik merupakan lembaga pendidikan dasar yang diikuti oleh anak-anak, yang jika dikontekskan dengan masa sekarang adalah anak-anak usia TK hingga SD. Kuttab diidentikkan dengan tempat belajar mengajar Alquran yang pada zaman dahulu berada di tempat guru atau sahabat nabi (Idi, 2015; Batubara and Ariani, 2016; Fathurrahman, 2017).

Mengacu pada kuttab di masa lampau, Kuttab Al Jazary menyelenggarakan pendidikan dasar bagi anak-anak. Sedikit berbeda dengan kuttab pada awal perkembangan Islam yang menjadikan anak usia TK hingga SD sebagai santrinya, Kuttab Al Jazary justru mensyaratkan kepemilikan ijazah TK bagi calon santri. Artinya bahwa Kuttab Al Jazary diperuntukkan bagi anak usia SD yang sebelumnya telah menempuh pendidikan di TK. Dilihat dari tempat penyelenggaraan Kuttab, telah terjadi pergeseran menyesuaikan perkembangan zaman. Kuttab pada masa lampau sebagian besar menjadikan rumah guru sebagai tempat belajar membaca dan menulis Alquran. Sementara Kuttab Al Jazary dan kuttab di Indonesia pada umumnya menyelenggarakan 
pendidikan dasar di dalam gedung layaknya sekolah dan madrasah.

Kurikulum kuttab pada awal perkembangan Islam masih sangat sederhana, berupa baca tulis, hafalan Alquran, dan pokokpokok ajaran Islam (Idi, 2015; Muspiroh, 2019). Pokok-pokok ajaran Islam yang diajarkan di Kuttab misalnya tentang puasa, berwudu, salat, dan sebagainya (Muspiroh, 2019). Kurikulum kuttab pada peradaban Islam klasik memiliki beberapa karakteristik, diantaranya adalah pelajaran Al-Quran yang dijadikan tema utama yang diajarkan di lembaga kuttab. Namun demikian. Kuttab pada masa peradaban Islam klasik juga memberikan pendidikan akhlak, pelajaran seni, olah raga, dan bahasa Arab (Putranto, 2016):

Jika dibandingkan dengan kurikulum Kuttab pada zaman klasik, Kuttab Al Jazary mengembangkan kurikulum yang tidak jauh berbeda, yang diklasifikasikan menjadi tiga jenis pendidikan, yaitu 1) pendidikan Alquran, 2) pendidikan adab; 3) pendidikan ilmu.
Pendidikan Alquran diterapkan dengan alokasi waktu hingga $70 \%$ dari total jam pelajaran yang ada. Target yang ingin dicapai adalah anak mampu menghafal 30 juz Alquran atau minimal 24 juz dengan hafalan yang mutqin (lancar dan baik). Sedangkan target minimal anak mampu menyelesaikan 24 juz dari Alquran dengan hafalan yang mutqin. Kuttab AL Jazary juga memberikan pelajaran bahasa Arab untuk memudahkan santri memahami kandungan isi Alquran.

Pendidikan Alquran yang diterapkan di Kuttab Al Jazary memiliki perbedaan dengan Kuttab Al Fatih yang merupakan inspirator berdirinya kuttab-kuttab di Indonesia. Kuttab Al Fatih Tangerang Selatan misalnya, santri ditargetkan mampu menghafal minimal tujuh juz selama menimba ilmu di Kuttab ini (Daylis, 2019). Sementara Kuttab Al Jazary memiliki target hafalan minimal 24 juz dan maksimal 30 juz bagi para santrinya selama bersekolah di kuttab. Adapun rincian target hafalan dilihat dari jenjang kelas dapat dilihat pada Tabel 4.

Tabel 4. Target hafalan siswa Kuttab Al-Jazary berdasarkan jenjang kelas

\begin{tabular}{ccccc}
\hline \multirow{2}{*}{ Kelas } & \multicolumn{4}{c}{ Target hafalan } \\
& Maksimal & Juz & Minimal & Juz \\
\hline I & 3 & $30,29,28$ & 2 & 30,29 \\
II & 4 & $27,26,25,24$ & 3 & $28,27,26$ \\
III & 6 & $1,2,3,4,5,6$ & 4 & $25,1,2,3$ \\
IV & 6 & $7,8,9,10,11,12$ & 5 & $4,5,6,7,8$ \\
V & 6 & $13,14,15,16,17,18$ & 5 & $9,10,11,12,13$ \\
VI & 5 & $19,20,21,22,23$ & 5 & $14,15,16,17,18$ \\
Total & & 30 juz & & 24 juz \\
\hline
\end{tabular}

Sumber: (Profil Kuttab Al Jazary, 2019)

Selain pendidikan Alquran, Kuttab Al Jazary juga memberikan pendidikan adab kepada para santrinya. Jika dikaitkan dengan ciri kuttab pada peradaban Islam klasik, pendidikan adab sangat relevan dengan pendidikan akhlak yang diberikan pada masa awal perkembangan Islam. Pendidikan adab yang diterapkan Kuttab Al Jazary tidak terbatas pada lingkungan kuttab saja, melainkan pemantauan akhlak dan adab santri di rumah melalui buku pantauan adab. Pendidikan adab lebih mengarahkan santri kepada ranah afektif, tidak sekedar ranah kognitif saja. Pembiasaan berdoa, salat Duha, salat Zuhur dan asar berjamaah, membiasakan senyum sapa dan salam, serta pantauan kegiatan di rumah menjadi muatan yang bersifat afeksi.

Selain pendidikan Alquran dan adab, Kuttab Al Jazary juga memberikan pendidikan ilmu berupa olah raga, berhitung (hisab), dan pelajaran lain yang disesuaikan dengan tuntutan kurikulum kementerian agama, mengingat Kuttab Al Jazary adalah penyelenggara pendidikan kesetaraan yang legalitasnya dikeluarkan oleh Kementerian Agama. Pendidikan ilmu bertujuan menyampaikan ilmu pengetahuan pada para santri. Meski target utama adalah mencetak generasi penghafal Alquran, Kuttab Al Jazary juga memberikan muatan-muatan di luar Alquran. Muatan umum 
yang diberikan misalnya Hisab (berhitung), olah raga, bahasa Indonesia, PKn, IPA, dan IPS.

Pada masa pemerintahan khalifah Umar bin Khattab, terdapat pembaruan kurikulum kuttab, dimana Khalifah Umar menginstruksikan untuk memberikan materi memanah, berenang, mengendarai kuda, dan bahasa Arab (Idi, 2015). Hal ini juga ada di dalam muatan tambahan Kuttab Al Jazary, yang dikemas dalam kegiatan outing class, yaitu proses belajar mengajar di luar kampus. Kegiatan outing class ini diisi dengan memanah, berkuda, berenang, halaqah di ruang terbuka, dan lain-lain.

Kuttab Al Jazary menggunakan metode talaqqi untuk mengajarkan santrinya bagaimana menghafal Alquran. Metode talaqqi adalah pembelajaran Alquran yang dilakukan dengan cara berhadap-hadapan antara asatizh dan santri, dimana asatizh secara langsung dan individual memperdengarkan Alquran secara berulang kepada santri (Qawi, 2017). Metode ini dipilih mengingat usia santri yang berkisar antara 6 sampai 7 tahun pada kelas I yang belum semuanya bisa membaca Alquran. Metode Talaqqi ini juga diakui merupakan metode yang diterapkan oleh Malaikat Jibril pada saat memberikan wahyu pertamanya kepada Nabi Muhammad, selanjutnya disampaikan kepada para sahabat dan diteruskan kepada para tabi 'in hingga akhirnya sampai kepada umat Islam sampai saat ini. Dengan metode ini diakui dapat mengurangi kesalahan santri dalam menghafal Alquran (UA, wawancara, 6 Desember 2019). Dengan demikian metode talaqqi yang diterapkan di Kuttab Al Jazary sudah merepresentasikan metode paling awal yang diterapkan dalam pembelajaran Alquran.

Dalam praktik pembelajaran, Kuttab Al Jazary menerapkan sistem halaqah untuk materi tahfizh Alquran dan sistem klasikal untuk mata pelajaran lainnya. Metode halaqah dan hafalan sendiri merupakan metode pendidikan Islam klasik yang diterapkan oleh kuttab-kuttab di awal perkembangan Islam (Chaer, 2015). Metode halaqah merupakan metode pembelajaran dimana seorang guru dalam memberikan pelajarannya dikelilingi oleh murid-muridnya (Nizar, 2013). Kuttab Al Jazary menerapkan metode halaqah dalam pembelajaran Alquran dengan membagi santri ke dalam dua kelompok halaqah pada setiap kelasnya. Satu halaqah terdiri dari 8 sampai 10 santri yang dibimbing oleh ustaz untuk kelas putra dan ustazah untuk kelas putri, dimana asatizh ini adalah para penghafal Alquran atau hafizh/hafizhah. Dengan metode halaqah ini pembelajaran Alquran dapat berjalan dengan efektif karena jumlah santri yang tidak terlalu banyak. Metode halaqah ini merupakan metode pembelajaran pada era pendidikan Islam klasik namun hingga kini masih diterapkan di berbagai lembaga pendidikan Islam.

\section{PENUTUP}

Kuttab Al Jazary Surakarta merupakan salah satu lembaga pendidikan nonformal yang memiliki karakteristik berbeda dengan kuttab di Indonesia yang pada umumnya mengacu pada Kuttab Al Fatih. Dilihat dari status kelembagaan, Kuttab Al Jazary memiliki legalitas sebagai program pendidikan kesetaraan tingkat ula yang dikeluarkan oleh Kementerian Agama dengan nama Madrasah Salafiyah Ula. Sedangkan secara umum kuttabkuttab di Indonesia memiliki legalitas sebagai PKBM di bawah Dinas Pendidikan setempat. Selain aspek legalitas, hal berbeda yang dimiliki Kuttab Al Jazary adalah sistem pendidikan dan kurikulumnya yang lebih mirip dengan karakteristik madrasah, hanya saja kurikulum Kuttab Al Jazary lebih menekankan kepada pembelajaran Alquran dengan target hafalan yang dicapai santri minimal 24 juz. Selain itu, jika kebanyakan madrasah menggunakan sistem klasikal dalam proses pembelajaran, Kuttab Al Jazary lebih banyak menerapkan sistem pembelajaran halaqah, khususnya dalam pembelajaran Alquran yang merepresentasikan model kuttab pada era pendidikan Islam klasik. Representasi pendidikan Islam klasik juga terlihat dari metode talaqqi yang diterapkan bagi santri dalam menghafal Alquran.

\section{DAFTAR PUSTAKA}

Batubara, H. H. and Ariani, D. N. (2016) 'Kuttab sebagai Potret Pendidikan Dasar Periode Klasik', Muallimuna, 1(2), pp. 98-111. doi: http://dx.doi.org/10.31602/muallimuna.v $1 \mathrm{i} 2.388$.

Beatrix, S. et al (2014) Quick Wins Percepat 
Langkah Kemenangan. Jakarta: Mizan Digital Publishing.

Chaer, M. T. (2015) 'Kuttab; Lembaga Pendidikan Islam Klasik', Al-Murabbi, $1(2)$, pp. 23-32.

Daulay, H. P. (2012) Pendidikan Islam dalam Sistem Pendidikan Nasional di Indonesia. Jakarta: Kencana Prenada Media Group.

Daulay, H. P. and Pasa, N. (2016) Pendidikan Islam dalam Lintasan Sejarah. Jakarta: Prenadamedia Group.

Daylis, D. S. (2019) Manajemen Perencanaan Kurikulum Al Fatih Tangerang Selatan. Universitas Islam Negeri Raden Intan Lampung.

El-Bantanie, M. S. (2018) Menyoal Masa Depan Sekolah Formal Konvensional. Available at: https://republika.co.id/berita/p24txd396/ menyoal-masa-depan-sekolah-formalkonvensional (Accessed: 17 December 2019).

Fahruddin, M. M. (2010) 'Kuttab: Madrasah pada Masa Awal (Umayyah) Pendidikan Islam', Madrasah, II(2), pp. 207-221. doi:

http://dx.doi.org/10.18860/jt.v2i2.1822.

Fathurrahman (2017) 'Eksistensi Kuttab dan Masjid sebagai Institusi Pendidikan Pada Masa Pertumbuhan Islam', Jurnal Ilmiah Kreatif, XIV(1), pp. 56-74.

Hidayat, F. (2017) 'Pertumbuhan Ideologi Pendidikan di Era Reformasi (Kajian terhadap Ideologi Pendidikan di Kuttab Al-Fatih Purwokerto)', Literasi, VIII(2), pp. 85-98. doi: //dx.doi.org/10.21927/literasi.2017.8(2).8 5-98.

Idi, A. (2015) Dinamika Sosiologi Indonesia. Yogyakarta: LKiS Printing Cemerlang.

Kuttab Al-Fatih (2020). Available at: https://www.kuttabalfatih.com/ (Accessed: 16 January 2020).

Kuttab Al Jazary (2019). Available at: https://jicsolo.com/kuttab-al-jazary/ (Accessed: 16 January 2020).

Mahasnah, M. H. (2016) Sejarah Peradaban
Islam. Jakarta Timur: Pustaka Al-Kautsar.

Makdisi, G. A. (2005) Cita Humanisme Islam. Jakarta: Serambi Ilmu Semesta.

Masyhuri, S. (2007) 'Transformasi Tradisi Keilmuan dalam Islam: Melacak Akar Kemunculan dan Perkembangan Institusi Pendidikan Islam', Hunafa, 4(3), pp. 227236. doi: https://doi.org/10.24239/jsi.v4i3.215.227 $-236$.

Muspiroh, N. (2019) 'Kuttab sebagai Pendidikan Dasar Islam dan Peletak Dasar Literasi', Tamaddun, 7(1), pp. 169192. doi: 10.24235/tamaddun.v7i1.4506.

Nata, A. (2003) Manajemen Pendidikan. Jakarta: Kencana.

Nata, A. (2010) Ilmu Pendidikan Islam. Jakarta: Kencana Prenada Media Group.

Nizar, S. (2013) Sejarah Sosial dan Dinamika Intelektual Pendidikan Islam di Nusantara. Jakarta: Kencana.

Profil Kuttab Al Jazary (2019). Surakarta.

Putra, A. A. R. (2012) Hope, Dream, Desire, Destiny. Jakarta: Elex Media Komputindo.

Putranto, S. D. (2016) Sistem Pendidikan Islam Model Kuttab. Universitas Islam Negeri Maulana Malik Ibrahim Malang.

Qawi, A. (2017) 'Peningkatan Prestasi Belajar Hafalan Al-Qur'an Melalui Metode Talaqqi Di MTsN Gampong Teungoh Aceh Utara', Islam Futura, 16(2), pp. 265-283. doi: http://dx.doi.org/10.22373/jiif.v16i2.132 7.

Rahman, K. (2018) 'Perkembangan Lembaga Pendidikan Islam di Indonesia', Tarbiyatuna, 2(1), pp. 1-14.

Ramadhan, I. W. (2019) 'Pendidikan Islam Model Kuttab dan Maktab', in Syarif, Z. (ed.) Sejarah Sosial dan Intelektual Pendidikan Islam. Batu: Literasi Nusantara.

Rouf, M. (2016) 'Memahami Tipologi Pesantren dan Madrasah sebagai Lembaga Pendidikan Islam di Indonesia', Tadarus, Jurnal Pendidikan Islam, 5(1), 
pp. 68-92.

Saputri, A. D. (2017) Reaktualisasi Kuttab dalam Pendidikan Islam di Sekolah Tahfidz Tingkat Dasar Tabarok Surakarta. Institut Agama Islam Negeri Surakarta.

Siroj, S. A. (2006) Tasawuf sebagai Kritik Sosial. Bandung: Mizan Pustaka.

Suwendra, I. W. (2018) Metode Penelitian Kualitatif dalam Ilmu Sosial, Pendidikan, Kebudayaan, dan Keagamaan. Badung: Nilacakra.

Syarifuddin, A. (2004) Mendidik Anak Membaca, Menulis, dan Mencintai AlQuran. Jakarta: Gema Insani Press.

Tentang Rumah Tahfidz (2020). Available at: http://rumahtahfidz.or.id/profil/rumah/ta hfidz/ (Accessed: 16 January 2020).

Ulwiyah, N., Maftuhatin, L. and Samsukadi, M. (2018) 'Implementation of Islamic Character Education with Intervention
Approach and Micro Habituation of Education In Kuttab Al Fatih Jombang', Didaktika Religia, 6(2), pp. 245-272. doi: 10.30762/didaktika.v6i2.1106.

Umar, H. (2003) Metode Riset Bisnis. Jakarta: Gramedia Pustaka Utama.

Umar, S. (2019) Pendidikan Masyarakat Berbasis Masjid. Yogyakarta: Deepublish.

Yaman, B. and Gultom, F. B. (2017) 'Islamic Education System: Implementation of Curriculum Kuttab Al-Fatih SemarangNo Title', World Academy of Science, Engineering and Technology International Journal of Educational and Pedagogical Sciences, 11(12), pp. 27922798. doi: 10.5281/zenodo.1314881.

Zuhdi, A. (2012) 'Madrasah sebagai Tipologi Lembaga Pendidikan Islam (Kajian tentang Berbagai Model Madrasah Unggulan)', Madrasah, 5(1), pp. 1-8. doi: http://dx.doi.org/10.18860/jt.v0i0.2230. 